\title{
CALL FOR PROPOSALS
}

Butterworths announces the initiation of a series of monographs entitled Perspectives on Individual and Population Aging, and welcomes proposals from prospective authors. Each monograph (to be 120-125 pages in length) will include an introduction, a critical review of the literature, the presentation of current research findings, some policy and problem implications drawn therefrom, and some unanswered research questions. The object of each monograph is to provide students. teachers, policymakers, professionals and laypeople with information that can be used when working with or for aging Canadians.

\section{Write:}

Ms. J. Tumer, Managing Editor, Butterworths, 2265 Midland Avenue. Scarborough. Ontario. Canada MIP 4SI.

Dr. B.D. McPherson.(Series Editor). Faculty of Human Kinetics and Liesure Studies. University of Waterloo, Waterloo, Ontario, Canada N2L 3GI.

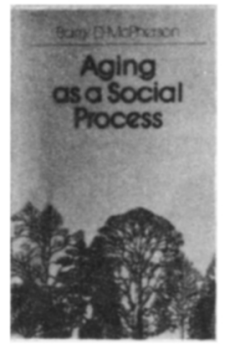

\section{AGING AS A SOCIAL PROCESS}

\author{
Barry D. McPherson
}

This text explains the process of individual and population aging by focusing on the interplay between the individual. social systems that influence his or her behaviour, and changing social, economic and physical environments. Employing various theoretical and methodological perspectives, it synthesizes recent theory and research in the growing discipline of social gerontology and raises intriguing questions for future research.

$040984830-1$

468 pages

*Price includes packaging and delivery and is subject to change without notice.

\section{BUTTERWORTHS}

2265 Midland.Avenue, Scarborough, Ontario, Canada

M1P 4S1 (416) 292-1421 


\section{Instructions to Authors}

1. Manuscripts should be sent to:

Dr. Blossom T. Wigdor,

Editor-in-Chief, Canadian Journal on Aging.

c/o Programme in Gerontology.

University of Toronto.

455 Spadina Ave., Room 407

Toronto, Ontario M5S IA1

2. Articles in most cases should not exceed $\mathbf{2 0}$ pages in length including references, tables and illustrations. Articles should be typed double spaced (including references) and submitted in quadruplicate ( 4 copies).

3. A title page must be included containing the name of the author, highest academic degree awarded, name and address of institutional affiliation. A condensed title for a running page headline not to exceed 40 letters and spaces should be supplied.

4. Abstract. Each author is required to furnish on a separate sheet an abstract of not more than 100-150 words. A French translation of the abstract is necesary. The author must provide this or accept the expense of the translation of the abstract.

5. Style of Referencing. The articles submitted to the Psychology, Social Science and Social Welfare sections should be written in the American Psychological Association style of referencing. The Biological and Health Science sections should be written using the Vancouver style. If more appropriate the APA style may also be used in these sections.

6. Tables. Tables should be typed on separate sheets. They should be referenced according to the particular referencing style adopted.

7. Figures. Figures should be submitted in a form ready for publication. The cost of reproduction of complex figures will be borne by the author.

8. Authors' alterations of the page proofs in excess of 10 per cent of cost of composition will be charged to the author.

9. Submission of a paper to this Journal implies that it has not been published or under consideration by another Journal, and if accepted for this Journal, is not to be published elsewhere (except as Society Proceedings) without permission.

10. Authors are asked to indicate for which division they feel their manuscript is most appropriate.

\section{Renseignements generaux aux auteurs}

1. Adresser les manuscrits a:

Dr. Blossom T. Wigdor, Rédacteur en chef

Revue canadienne du vieillissement

a/s Programme de gérontologie

Université de Toronto

455, avenue Spadina, Bureau 407

Toronto, Ontario M5S 1A1.

2. Les articles ne doivent pas dépasser 20 pages, références, illustrations et tableaux compris. Ils doivent être dactylographiés à double interligne ( $y$ compris les références) et soumis en quatre exemplaires.

3. Les manuscrits comprennent une page de titre comportant les mentions suivantes: nom de l'auteur, diplome supérieur, nom et adresse de l'institution à laquelle il est affiliè. Il est recommandé de fournir un titre courant abrégé ne dépassant pas $\mathbf{4 0}$ caractères.

4. Résume. Les auteurs sont priés de fournir, sur une feuille à part, un résumé de 100 à 150 mots au maximum. Celui-ci devra être accompagné de sa traduction anglaise, à défaut de quoi les frais de traduction seront à la charge des auteurs.

5. Référénces. Les références citees dans les articles intéressant les sections Psychologie, Sciences sociales et Bien-ètre social doivent être conformes au protocole de I'American Psychological Association; celles qui accompagnent les articles soumis aux sections Biologie et Sciences de la sante doivent suivre le protocole de Vancouver, éventuellement celui de IA.P.A.

6. Tableaux. Les tableaux figurent sur des feuilles a part. Ils seront conformes au protocole adopté.

7. Schémas et diagrammes. Toute illustration doit être présentée sous une forme propre à la reproduction. Les frais de reproduction des illustrations complexes sont a la charge des auteurs.

8. Les corrections d'auteur excédant $10 \%$ du coût de la composition sont aux frais des auteurs.

9. La Revue ne fait paraitre que des articles inédits et n'examine que les manuscrits qui ne sont pas soumis concurrement à d'autres revues. Aucun article accepté par la Revue ne peut être reproduit, sauf dans les Actes de la Société, sans autorisation expresse.

10. Les auteurs sont priés d' indiquer le nom de la section à laquelle ils soumettent leur manuscrit. 